\title{
SEASONAL VARIATION OF NUTRIENTS AND ENERGY IN TAMBAQUI'S (Colossoma macropomum CUVIER, 1818) NATURAL FOOD
}

\author{
SILVA, J. A. M. da, ${ }^{1}$ PEREIRA-FILHO, M. $^{2}$ and OLIVEIRA-PEREIRA, M. I. de ${ }^{2}$ \\ ${ }^{1}$ IB/UFBA, CEP 40170-290, Salvador, BA, Brazil \\ ${ }^{2}$ CPAQ/INPA, C.P. 478, CEP 69084-00, Manaus, AM, Brazil \\ Correspondence to: Jorge Antonio Moreira da Silva, Instituto de Biologia, UFBA, CEP 40170-290, \\ Salvador, BA, Brazil, e-mail: jams@ufba.br \\ Received October 21, 1998 - Accepted May 29, 2000 - Distributed November 30, 2000
}

(With 7 figures)

\begin{abstract}
The aim of this study was to evaluate the importance of fruits and seeds as food items in the natural diet of the tambaqui (Colossoma macropomum). During one year, tambaqui's stomach contents were collected, and their nutritional and energetic values were determined. During the flooding period, and while the river water was rising, which coincided with a high availability of fruits and seeds, the protein content of food was low (11\%-15\% of dry matter basis), whereas in the dry season, when tambaqui fed mainly zooplankton, there was a high protein content (45\%-57\% of dry matter basis). Lipid, carbohydrate, crude fiber, ash and gross energy contents of the diet varied depending on the river water level and the food items ingested.
\end{abstract}

Key words: tambaqui, Colossoma macropomum, stomach content, seasonal variation, nutritional value.

\section{RESUMO}

Variação sazonal de nutrientes e energia do alimento natural do tambaqui (Colossoma macropomum Cuvier, 1918)

O objetivo deste estudo foi determinar o valor nutricional dos itens alimentares da dieta do tambaqui (Colossoma macropomum). Durante o período de um ano, foram coletados conteúdos estomacais do tambaqui e determinados os valores nutricionais e energéticos. Durante o período da enchente-cheia, época de maior disponibilidade de frutos e sementes, o teor protéico do alimento foi baixo (11\% a $15 \%$ da matéria seca), enquanto na época de seca, quando a espécie consome zooplâncton, os níveis de proteína foram altos ( $47 \%$ a $57 \%$ da matéria seca). Lipídios, carboidratos, fibra bruta, cinza e energia bruta também variaram em função das flutuações do nível da água e dos itens alimentares.

Palavras-chave: tambaqui, Colossoma macropomum, conteúdo estomacal, variação sazonal, valor nutritivo.

\section{INTRODUCTION}

The relationship between the Amazonian floodplain forest and the feeding behavior of some Amazonian fishes is of major importance, since some fish species are completely dependent on the food items that fall on the water surface, mainly leaves, flowers, fruits and seeds. Goulding (1996) states that fruits and seeds are major natural sources of nutrients and energy for at least 200 different Amazonian fish species. Currently, 112 species of fruits and seeds, distributed among 36 families and 15 morphological types, $63 \%$ of which are berries, drupes and capsules, have been identified as food of tambaqui (Silva et al., 1999). The tambaqui, Colossoma macropomum, is one of the 
Amazonian fishes that depends on these items. During the flooding period, such items represent the highest percentage of all material found in analysis of their stomach contents (Honda, 1974; Gottsberger, 1978; Smith, 1979; Goulding, 1980; Carvalho, 1981; Saint-Paul, 1986; Ziburski, 1990). This fact led some authors to consider adult individuals as strictly frugivorous (Eckmann, 1987; SaintPaul, 1991). Juveniles (<50 cm) are omnivorous and feed on zooplankton (Honda, 1974; Goulding, 1980; Carvalho, 1981).

This paper contains results of proximate analysis of tambaqui stomach contents, which were carried out during a hydrological cycle and also, some aspects of tambaqui's natural diet and feeding habits.

\section{MATERIALS AND METHODS}

\section{Collection and treatment of digestive tracts}

Most digestive tracts were collected at Panair's fish market, the major landing place for marketing of tambaqui in Manaus. There, one finds specimens captured at several different places of the Amazon basin.

Digestive tracts, counting from the beginning of the esophagus to the end of the rectum, were collected weekly from 15 specimens. Each one was placed in plastic bags, transferred to the laboratory with ice, and stored frozen until analysis. These collections were carried out from June to November, 1993, and from March to May, 1994. Sampling could not be from December 1993 to February 1994, because fishing was forbidden at that time of the year to allow fish breeding.

Standard length $(\mathrm{cm})$, from the end of the muzzle to the base of the caudal fin as well as body weight $(\mathrm{Kg})$ were taken before the specimens where gutted.

Some tambaqui specimens $(17,2 \%)$ were also caught in "Lago do Rei" and "Lago Grande" (Manaquiri, Amazonas State, Brazil). A total of 685 digestive tracts were sampled. Table 1 show the number and percentage of individuals analyzed by size class.

TABLE 1

Percentage and number of analyzed individuals for class of standard lenght.

\begin{tabular}{|c|c|c|}
\hline SL (cm) & (n) & (\%) \\
\hline $10-19$ & 7 & 1.02 \\
\hline $20-29$ & 90 & 13.13 \\
\hline $30-39$ & 21 & 3.06 \\
\hline $40-49$ & 131 & 19.14 \\
\hline $50-59$ & 228 & 33.28 \\
\hline $60-69$ & 148 & 21.62 \\
\hline $70-79$ & 51 & 7.44 \\
\hline $80-89$ & 9 & 1.31 \\
\hline
\end{tabular}

$\mathrm{SL}=$ Standard lenght $\mathrm{n}=$ number of individuals.

The stomach's degree of repletion was evaluated, by considering only two categories:

1) empty or 2) containing food items. The number of stomachs with food as well as variations on the level of nutrients and energy were related to the river water level, which were based on records for Negro river measured at Manaus harbor. Stomach contents were weighed and divided in two parts: one was kept in $10 \%$ formalin solution, and used for the identification of the food items, and the other was frozen for further liofilization and determination of its nutritional and energetic content.

\section{Analytical methods}

Proximate analysis and gross energy determination were carried out in the Fish Nutrition Laboratory/CPAQ/INPA, in Manaus, Amazonas State, Brazil. Qualitative evaluations were made through Weende method, according to A.O.A.C. 
(1980). Samples were homogenized and analyzed in triplicate. Pre-drying was determined through liofilization and then weighed at room moisture. Water lost during the pre-drying step plus water loss for determining dry matter (DM) was taken into account for the estimation of moisture level.

\section{Determination of nutrients}

Crude protein (CP) was determined by quantifying whole nitrogen through the micro-Kjeldahl method, using the conversion factor $(\mathrm{N} \times 6.25)$. Lipids (EE) were determined by continuous extraction with petroleum ether in a Soxleth extractor. Crude fiber (CF) was obtained by double acid $\left(\mathrm{H}_{2} \mathrm{SO}_{4}, 0.25 \mathrm{~N}\right)$ and alkaline $(\mathrm{NaOH}, 0.25 \mathrm{~N})$ sample digestion. Ash content was determined incinerating the sample in a kiln during $3 \mathrm{~h}$ at $550^{\circ} \mathrm{C}$. Carbohydrate level were estimated through the difference. Nutrient and energy fractions were expressed as related to dry matter basis (DM). Gross energy (GE) was determined using a calorimetric bomb.

\section{RESULTS}

The Fig. 1 shows the frequency of stomachs with food, according to tambaqui's capture season. During the period of highest availability of fruits and seeds (water rising and flooding) most specimens had food items in their stomachs, the highest incidence begins of April (98.4\%).

When the river water is at its lowest level (dry season), more than $50 \%$ of all stomachs were empty.

During river water rising in the flooding months, the frequency of stomachs containing fruits and/or seeds was considerably higher. The coincided with the fructification period of the trees present in the swampy areas and "igapó" type forests in the Amazonian region.

During the months of less occurrence of food filled stomachs, specimens showed a greater amount of cavitary fat (up to $10 \%$ of the specimen's total weight). This is an adaptation of the species for energy supply during periods of food shortage.
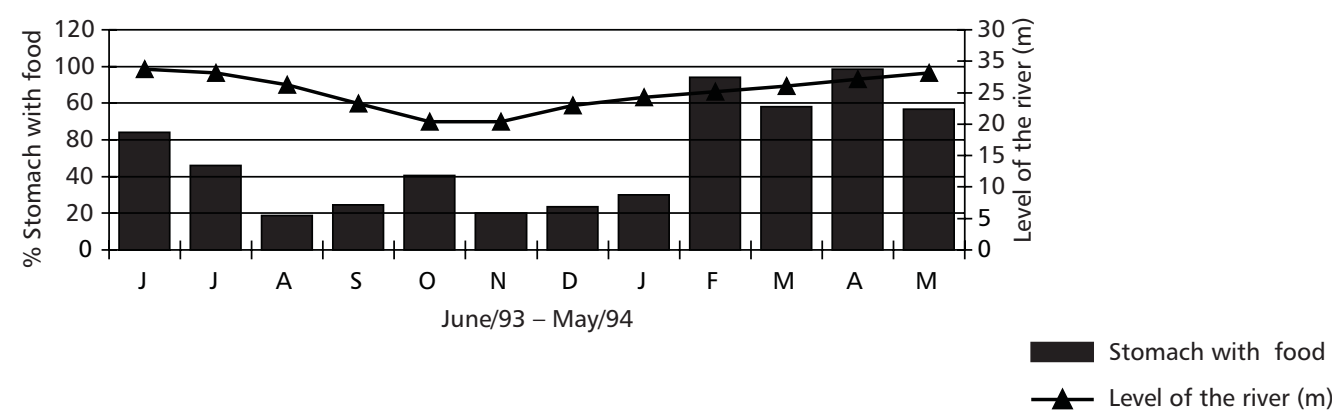

Fig. 1 - Frequency of stomachs with food items during the capture period.

\section{Stomach contents, nutritional and energetic values}

Out of the 685 digestive tracts sampled, $45.3 \%$ (310) contained enough material to enable identification and analysis, and in $47.4 \%$ (147) contained enough sample for determining proximate composition.

Food nutrient availability varied widely during the annual tambaqui's feeding cycle. During the period of highest fruits and seeds availability (March to August), the level of crude protein wes under $15 \%$
(DM basis), while during the period of less occurrence of these food items (September to November), mean protein level was above $44 \%$ (Fig. 2). This increase in the protein content of tambaqui's diet is related to the consumption of zooplankton, from which the species obtains the highest amount of dietary animal protein. The highest level of lipid in the diet were observed during April (31.1\%) and May $(29.2 \%)$, when many fruits and seeds were available. Usually this nutrient remained less variable than protein throughout the year (Fig. 3). 


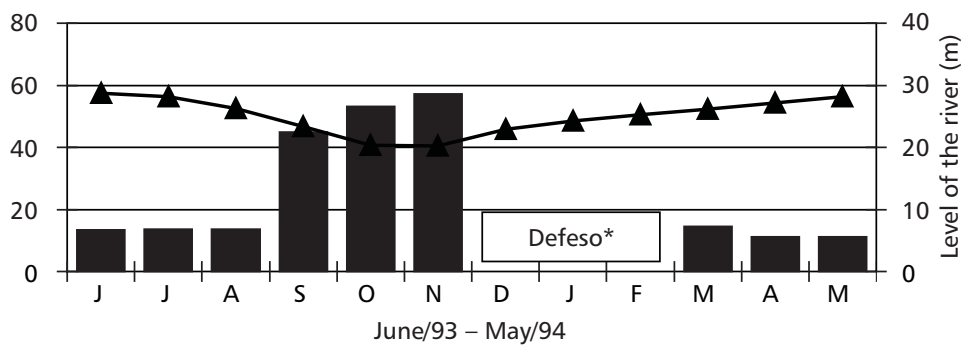

Nutrient

$\rightarrow$ Level of the ri

Fig. 2 - Monthly average crude protein (CP) level in tambaqui's stomach contents. *Period in which fishing is forbidden by law.

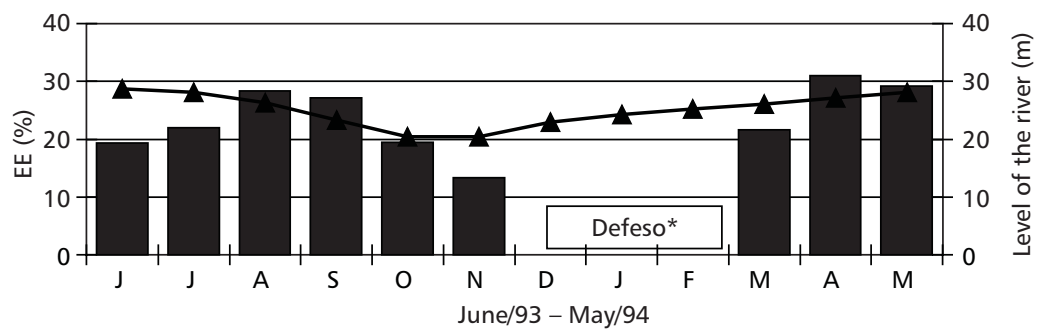

Nutrient (EE)

Level of the river $(\mathrm{m})$

Fig. 3 - Monthly average lipid (EE) level in tambaqui's stomach contentes. *Period in which fishing is forbidden by law.

Carbohydrate mean levels fluctuation in tambaqui's stomach contents are shown in Fig. 4. Tambaqui presented the highest availability $(42.5 \%)$ of this nutrient when fruits and seeds were the major food items in its natural diet. In the period from September to November, tambaqui's diet presented very low carbohydrate level due particularly to the prevalence of items from animal origin.

Monthly mean crude fiber levels presented similar to carbohydrate values fluctuation. During months when fruits and seeds were the major items in the diet of the species, the level of crude fiber varied between $9.7 \%$ and $20.5 \%$ (Fig. 5).

The period that presented the highest ash level coincided with the period of less occurrence of fruits and seeds, which was September to November (Fig. 6). The highest ash value (14.7\%) occurred in October.

This fact may be related to the tambaqui's opportunistic feeding behavior: when fruits and seeds were not available, they fed on animal sources items, particularly zooplankton.

The Fig. 7 presents the gross energy variation throughout the study period. There was not much difference between periods of high and low fruits and seeds availability. These values ranged from 484.6 Kcal GE/100 g in June, to 574.2 Kcal GE/ $100 \mathrm{~g}$ in May. These results indicate that items with different nutritional composition can be found in a feeding meal, providing a higher or lower levels of energy depending on their concentration. 


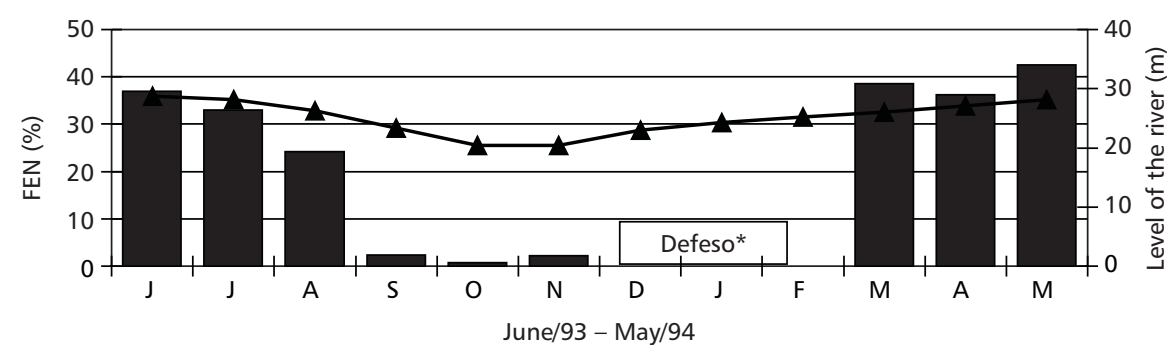

Nutrient (FEN)

$\longrightarrow$ Level of the riveı

Fig. 4 - Monthly average carbohydrates (FNE) concentration in tambaqui's stomach contents. *Period in which fishing is forbidden by law.

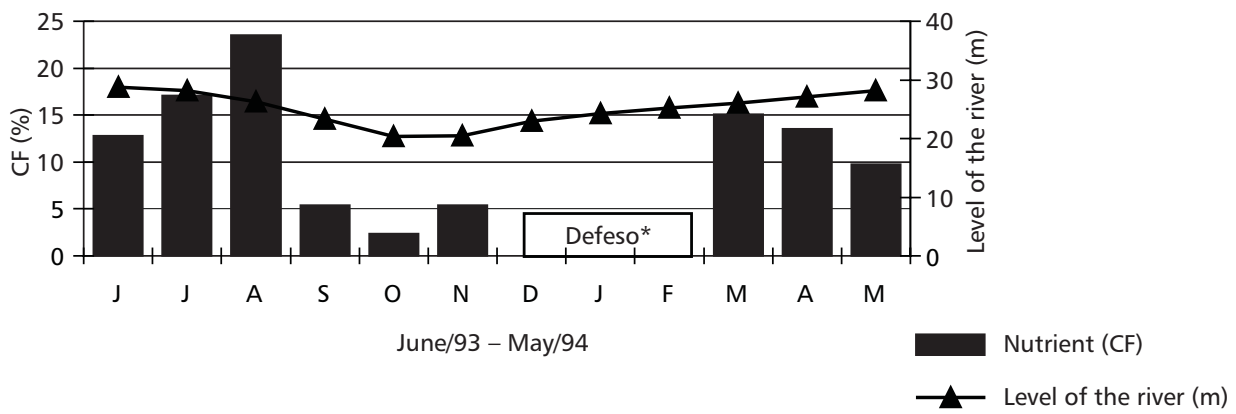

Fig. 5 - Monthly average crude fiber (CF) concentration in tambaqui's stomach contents. *Period in which fishing is forbidden by law.

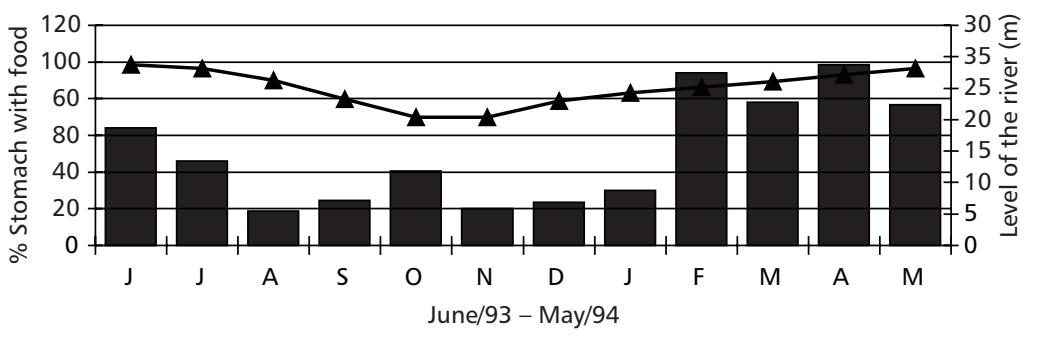

Fig. 6 - Monthly average ash level in tambaqui's stomach contents. *Period in which fishing is forbidden by law.

\section{DISCUSSION}

Tambaqui is considered an omnivorous species, conditioned by the food availability within the environment, which is seasonal in the Amazon region. Feeding activity is more intense in the period of flooding, when there is a greater availability of food items produced by the flooded forest. 


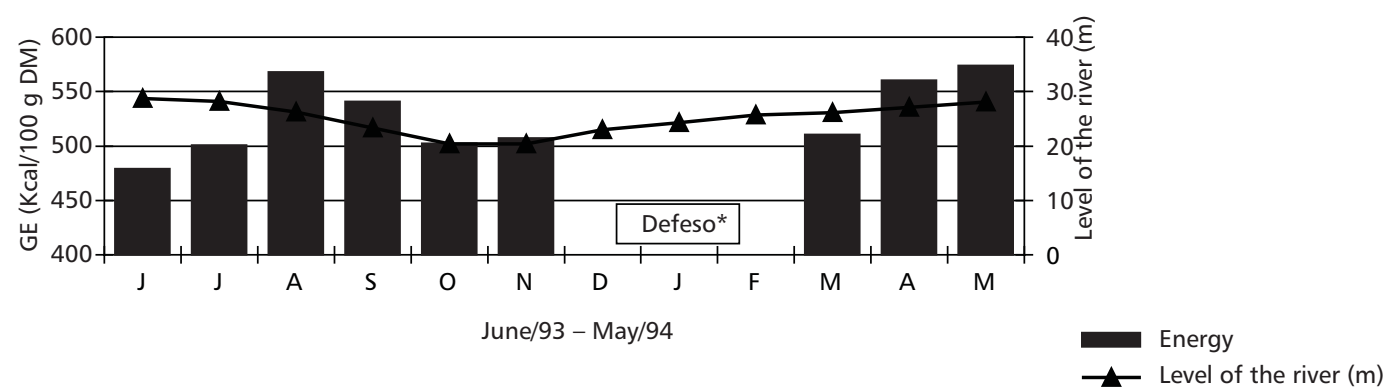

Fig. 7 - Monthly average gross energy in tambaqui's stomach contents. *Period in which fishing is forbidden by law.

Although the term omnivorous is applied for describing the trophic ecology of tambaqui, such terms as frugivorous, herbivorous, and zooplanktophagous have been found in literature, and may be applied when the distinct periods of river water level fluctuations are taken into account.

The degree of repletion of tambaqui stomachs within the study period represented food availability in the high period of flooding, when higher percentage of full stomachs were observed. Within this period, the species actively fed on fruits and seeds. However, tambaqui fed on zooplankton when these items become scarcer, as has already been observed by Honda (1974), Goulding (1980) and Carvalho (1981). Tello et al. (1992) also observed a direct relationship between frequency of empty and full stomachs to food availability within season periods, when studying the bioecology of 46 commercial value fish species from lower Ucayali and Marañon rivers in Peru.

The variation in stomach content nutrient and energy levels, has shown that food is very rich in the period of greater availability of fruits and seeds. Mean values of $36.8 \%$ of carbohydrates, $24.7 \%$ of lipids, $14.8 \%$ of crude fiber, and $12,6 \%$ for protein, which was relatively lower.

Higher levels of protein were observed during the dry season, the period of greater availability of zooplankton. Tambaqui's has to fulfill its nutrient requirements for growth, balancing protein from animal and vegetable origin. Zooplankton $(51.1 \%$ protein) is the most important source for this nutrient, within its yearly feeding cycle. In adults, this source of protein is very important for the maturation of the gonads. Following the dry period, comes the flooding, which is the time for mating and spawning of this species.

Protein in any diet is employed by organisms for tissue repair and maintenance, growth and reproduction. The intake of diets with high protein levels provides more than enough aminoacids, and the surplus may be used for energetic purposes, and not for growth (De La Higuera, 1987). As fruits and seeds are poor sources of protein, it may be possible that tambaqui uses only lipids and carbohydrates present in higher levels in its diet, as the major sources of energy as an "sparing protein effect" (Hepher, 1988). Pezzato (1990) noted this protein sparing effect in pacu (Piaractus mesopotamicus), when replacing usual sources of food energy by animal fat sources.

It's common for monogastrics to consume food to satisfy their energy requirements. There is a close relationship between a full stomach and consumption of energy (Barros et al., 1988). In a well balanced diet, fish may compensate for a low energy content through an increase in large amounts of food consumption (Cho, 1987). Tambaqui balances between protein/energy though consuming fruits and/or seeds containing low levels of protein. This was noted with jauari fruit (Astrocaryum jauari) which was eaten in large quantities more often than other fruits. However, proximal analysis revealed that this fruit contained low levels of crude protein $(5 \%)$, high level of carbohydrates $(45.6 \%)$ and crude fiber $(32.5 \%)$. The caloric value of this fruit $(486.1 \mathrm{Kcal}$ $\mathrm{GE} / 100 \mathrm{~g}$ ) is above the average of the other fruits (442.2 Kcal GE/100 g). However, the digestible energy of their seeds was the lowest $(92.7 \mathrm{Kcal}$ GE/ $100 \mathrm{~g}$ ) when compared with other seeds. 
Tambaqui has to feed on items of varied composition to achieve a balanced diet to attend its metabolic needs. However, some stomachs were full of only one fruit or seed type, as in the case of jauari (Astrocaryum jauari) and seringa barriguda (Hevea spruceana). These findings state the opportunistic characteristic of the species, which consumed items that were more available within its habitat.

As noted by Goulding (1980), there is a relationship between tambaqui's diet and floodplain forests. Therefore, fruits and seeds make up a set of nutrients and energy which must be preserved for the enhancement for this species in its own original habitat.

Thus, we conclude that tambaqui feeds abundantly on fruits and seeds, which represent its energy source during the flooding period. During the dry period, which coincides with the maturation of its gonads, tambaqui feed on protein rich sources such a zooplankton. After the dry period comes the flooding period, when the species mate and spawn to guarantee its perpetuity.

Acknowledgments - The authors would like to thank CNPq (Research National Council for the financial support and Dra. Débora Fracalossi for her helping hand in the manuscript translation.

\section{REFERENCES}

A.O.A.C., 1980, Association Of Official Analytical Chemists. Official methods of analysis. Washington D.C., $13^{\text {th }}$ Edition, 937 p.

BARros, M. M., PEZZATO, L. E., SIlveIRA, A. C. \& PEZZATO, A. C., 1988, Digestibilidade aparente de fontes alimentares alternativas pela Tilápia do nilo Oreochromis niloticus. AN. VI SIMP. LATINOAMERICANO E V SIMP. BRASILEIRO DE AQÜICULTURA, Florianópolis, SC, Brasil, pp. 428-432.

CARVALHO, M. L., 1981, Alimentação do tambaqui jovem (Colossoma macropomum) e sua relação com a comunidade zooplanctônica do Lago Grande - Manaquiri, Solimões - AM. Dissertação de Mestrado. INPA/FUA, Manaus, AM, 91p.

CHO, C. Y., 1987, La energía en la nutrición de los peces, pp. 197-237. In: J. Espinosa de los Monteros \& U. Labarta (eds.), Nutrición en Acuicultura II., 318p., Madrid, España.
DE LA HIGUERA, M., 1987, Requerimientos de proteína y aminoácidos en peces, pp. 53-98. In: J. Espinosa de los Monteros \& U. Labarta (eds.), Nutrición en Acuicultura II., 318p., Madrid, España.

ECKMANN, R., 1987, Growth and body composition of juvenile Colossoma macropomum CUVIER, 1818 (Characidae) feeding artificial diets. Aquaculture, 64: 293-303.

GOULDING, M., 1980, The fish and the forest. Explorations in Amazonian Natural History. University of California Press, Los Angeles, 280p.

GOULDING, M., 1996, Pescarias Amazônicas, Proteção de Habitats e Fazendas nas Várzeas: Uma visão Ecológica e Econômica. Workshop: Projeto de Manejo dos Recursos Aquáticos, Belém, PA, 26 a 28 de março, 35p.

GOTTSBERGER, G., 1978, Seed dispersed by fish in the inundated regions of Humaitá, Amazonia. Biotropica, 10: 170-183.

HEPHER, B., 1988, Nutrition of Pond Fishes. Cambridge University Press, New York, 388p.

HONDA, E. M. S., 1974, Contribuição ao conhecimento da biologia de peixes do Amazonas. II. Alimentação do tambaqui, Colossoma bidens. Acta Amazonica, 4: 47-53.

PEZZATO, L. E., 1990, Efeito de níveis de gordura de origem animal e vegetal sobre o desempenho e deposição de ácidos graxos em pacu (Piaractus mesopotamicus). Tese de Doutorado, UNESP, Jaboticabal, São Paulo, 91p.

SAINT-PAUL, U., 1986, Potential for aquaculture of South American Freshwater fishes: a review. Aquaculture, 54: 205-240.

SAINT-PAUL, U., 1991, The potential for Colossoma culture in Latin America. Infofish International, 2: 49-53.

SILVA, J. A. M., PEREIRA-FILHO \& OLIVEIRAPEREIRA, M. I., 1999, Digestibility of seeds consumed by tambaqui (Colossoma macropomum Cuvier, 1818): an experimental approach. Biology of Tropical Fishes. Edited by A. L. Val and V. M. F. Almeida Val. Chapter 11, pp. 137-148, INPA, Manaus.

SMITH, N. J. H., 1979, A pesca no rio Amazonas. CNPq/ INPA, Manaus, AM, 154p.

TELlO, J. S., MONTREUIL, V. H., MACO, J. T., ISMIÑO, R. A. \& SÁNCHEZ, H., 1992, Bioecologia de peces de importancia economica de la parte inferior de los rios Ucayali y Marañon - Perú. Folia Amazonica, 4(2): 75-93.

ZIBURSKI, A., 1990, Ausbreitungs-und Reproduktionsbiologie einiger Baumarten der amazonischen Überschwemmungswälder. Tese de Doutorado, Universidade de Hamburg, Alemanha, 112p. 